\title{
Pengaruh Konsentrasi Gula Pasir dan Gula Aren pada Pembuatan Nata de Coco
}

\author{
Effect of Sugar and Palm Sugar Concentration in Making Nata de Coco \\ Fatimah $^{1 *}$, Nina Hairiyah ${ }^{1}$, Riski Yulia Rahayu ${ }^{1}$ \\ ${ }^{1}$ Jurusan Teknologi Industri Pertanian, Politeknik Negeri Tanah Laut, Jl. A. Yani, Km.6, \\ Desa Panggung, Kec. Pelaihari, Kab. Tanah Laut, Kalimantan Selatan 70815, Indonesia \\ Email: fatimah@politala.ac.id
}

Naskah diterima: 12 Agustus 2019; Naskah disetujui: 12 September 2019

\begin{abstract}
Sugar is commonly used as a source of nutrition in the media for making nata de coco. While, palm sugar have not been used as a source of nutrition in the media for making nata de coco. The purpose of this study is to determine the optimal concentration of palm sugar in making nata de coco. The treatments used variations in the concentration of sugar, namely $2 \%$ of sugar, $2 \%$ of palm sugar, and the ratio between $1 \%$ of sugar : $1 \%$ of palm sugar. Nata de coco measurements included nata thickness and yield. The best formulation for making nata de coco was in the treatment with a ratio of $1 \%$ sugar: $1 \%$ palm sugar, producing nata with $76 \%$ rendeman and $0.83 \mathrm{~cm}$ thick. While making nata using $2 \%$ concentration of sugar has a yield of $45 \%$ with a thickness of $0.46 \mathrm{~cm}$. Making nata using palm sugar was a very significant effect on yield of nata. Therefore, palm sugar can replace sugar in making nata de coco.
\end{abstract}

Keywords: Nata de Coco, Palm Sugar, Sugar

\begin{abstract}
ABSTRAK
Gula pasir sudah umum digunakan sebagai sumber nutrisi pada media pembuatan nata de coco. Sedangkan gula aren belum digunakan sebagai sumber nutrisi pada media pembuatan nata de coco. Tujuan dari penelitian ini adalah menentukan konsentrasi optimal gula aren dalam pembuatan nata de coco. Perlakuan yang digunakan adalah variasi konsentrasi gula, yaitu gula pasir $2 \%$, gula aren $2 \%$, dan perbandingan antara gula pasir $1 \%$ : gula aren \%. Pengukuran nata de coco meliputi ketebalan dan rendemen nata. Formulasi terbaik pembuatan nata de coco adalah pada perlakuan dengan konsentrasi perbandingan gula pasir $1 \%$ : gula aren $1 \%$, menghasilkan nata dengan rendeman $76 \%$ dan tebal $0,83 \mathrm{~cm}$. Sedangkan pembuatan nata menggunakan gula pasir konsentrasi $2 \%$ memiliki rendemen sebesar $45 \%$ dengan tebal $0,46 \mathrm{~cm}$. Pembuatan nata menggunakan gula aren berpengaruh sangat nyata terhadap rendemen nata, sehingga gula aren dapat menggantikan gula pasir dalam pembuatan nata de coco.
\end{abstract}

Kata Kunci : Nata de coco, Gula aren, Gula pasir 


\title{
PENDAHULUAN
}

Nata adalah lapisan polisakarida ekstraseluler (selulosa) yang dibentuk oleh kumpulan sel bakteri pembentuk kapsul. Lapisan ini mempunyai tekstur kenyal, putih, menyerupai gel dan terapung pada bagian permukaan cairan (nata tidak akan tumbuh di dalam cairan). Nata dikenal sebagai salah satu produk makanan fermentasi yang berbentuk gelatin seperti agar-agar atau kolang-kaling yang dapat dipakai sebagai bahan pengisi es krim, pencampur fruit cocktail, dan yoghurt. Bahan utama pembuatan nata de coco adalah air kelapa (Rizal, et al, 2013). Selain air kelapa, ada beberapa bahan lain yang dapat digunakan dalam pembuatan nata, antara lain nira aren (Lempang, 2016; Asri, et al., 2018), ampas buah sirsak (Suparti, et al., 2007), kulit buah naga (Hardianti et al., 2018).

Selama ini, gula pasir sudah sangat umum digunakan dalam pembuatan nata de coco (Rizal, et al., 2013); (Wardhana, et al 2016). Gula pasir merupakan sumber karbohidrat berupa disakarida (sukrosa) yang dimanfaatkan oleh bakteri Acetobacter xylinum sebagai sumber energi. Gula pasir merupakan sumber karbon untuk membentuk senyawa metabolit sekunder berupa selulosa yang disebut nata. Disamping gula pasir, gula aren juga merupakan sumber karbohidrat yang belum digunakan dalam pembuatan nata de coco. Penelitian penggunaan gula aren dalam pembuatan nata de coco belum dilaporkan. Tujuan penelitian untuk membandingkan formulasi terbaik antara penggunaan gula pasir dan gula aren dalam pembuatan nata de coco, dimana parameter pengukuran meliputi rendemen nata dan tebal nata.

\section{METODE PENELITIAN}

\author{
Alat \\ Alat yang digunakan dalam penelitian ini adalah panci, kompor gas, gelas beaker, \\ pengaduk, nampan plastik, baskom, piring plastik kecil, koran, karet gelang, masker, dan \\ sendok.
}

Bahan

Adapun bahan yang digunakan dalam penelitian ini adalah air kelapa, ZA, asam asetat 25\%, gula pasir, gula aren, dan starter bakteri Acetobacter xylinum. 


\section{Peremajaan Starter Bakteri Acetobacter xylinum}

Air kelapa disaring sebanyak 1 liter, kemudian dimasukkan kedalam panci, selanjutnya ditambahkan dengan gula pasir sebanyak $20 \mathrm{~g}$ dan ZA sebanyak 2,5 g dan direbus sampai mendidih sambil diaduk. Setelah itu, media yang masih dalam keadaan panas ditambahkan dengan asam asetat 25\% sebanyak $40 \mathrm{ml}$ sambil diaduk. Media selanjutnya disaring sambil dimasukkan secara aseptis kedalam botol yang telah disterilkan sebanyak $400 \mathrm{ml}$. Botol yang telah berisi media panas selanjutnya ditutup dengan koran steril, diikat dengan karet dan didiamkan selama 4 jam pada suhu ruang, kemudian ditambahkan $100 \mathrm{ml}$ starter bakteri Acetobacter xylinum. Starter bakteri diinkubasi selama 6 hari pada suhu ruang, selanjutnya starter siap digunakan untuk pembuatan nata de coco.

\section{Pembuatan Nata de Coco}

Air kelapa disaring sebanyak 1 liter dimasukkan kedalam panci, setelah disaring kemudian direbus bersama dengan perlakuan perbandingan berat antara gula pasir dan gula aren masing-masing $20 \mathrm{~g}: 0 \mathrm{~g}, 10 \mathrm{~g}: 10 \mathrm{~g}$, dan $0 \mathrm{~g}: 20 \mathrm{~g}$. Pada masing-masing perlakuan ditambahkan dengan ZA sebanyak 2,5 $\mathrm{g}$ dan direbus sampai mendidih sambil diaduk. Setelah itu, media yang masih dalam keadaan panas ditambahkan dengan asam asetat 25\% sebanyak $40 \mathrm{ml}$ sambil diaduk. Media selanjutnya disaring sambil dimasukkan secara aseptis kedalam nampan yang telah disterilkan sebanyak $400 \mathrm{ml}$. Nampan yang telah berisi media panas selanjutnya ditutup dengan koran steril, diikat dengan karet dan didiamkan selama 4 jam pada suhu ruang, kemudian ditambahkan 100 $\mathrm{ml}$ starter bakteri Acetobacter xylinum. Media nata de coco difermentasi selama 7 hari pada suhu ruang, selanjutnya nata de coco dipanen (Modifikasi metode dari Wardhana et al. 2016).

\section{Penentuan Rendemen Nata}

Nata yang telah difermentasi selama 7 hari, kemudian diangkat dan diukur meliputi tebal dan berat nata. Hitung rendemen nata dengan rumus:

$\%$ Rendemen nata $=\frac{\text { Berat nata }(g)}{\text { Berat media }(g)} \times 100$ 


\section{Analisis Data}

Data yang diperoleh kemudian dianalisis menggunakan Uji sidik ragam/ Analysis of Varians (ANOVA), selanjutnya apabila perlakuan berpengaruh nyata, maka dilakukan uji lanjut menggunakan DMRT (Hanafiah, 2011).

\section{HASIL DAN PEMBAHASAN}

Pembuatan nata de coco dilakukan dengan variasi konsentrasi gula pasir dan gula aren. Berikut adalah hasil dari pembuatan nata de coco dari variasi konsentrasi gula pasir dan gula aren dapat dilihat pada Gambar 1 dan Tabel 1.

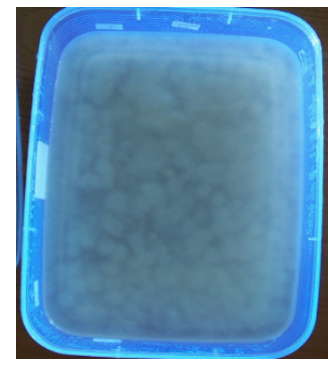

A

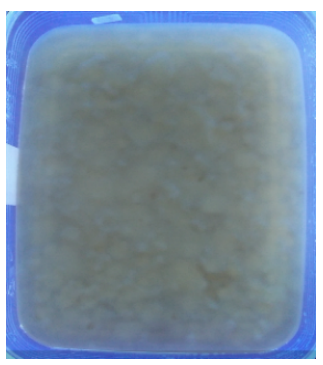

B

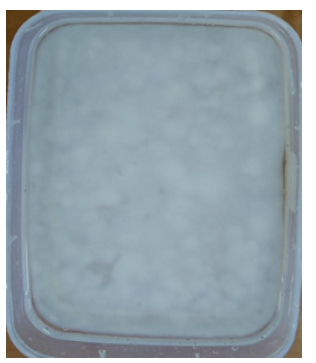

$\mathrm{C}$

Gambar 3. A. Nata de coco dengan konsentrasi gula pasir $2 \%$; B. Nata de coco dengan konsentrasi gula aren $2 \%$; C. Nata de coco dengan konsentrasi gula pasir $1 \%$ : gula aren $1 \%$.

Tabel 1. Tebal, Berat, dan Rendemen Nata de Coco

\begin{tabular}{cccc}
\hline Perlakuan & Tebal nata (cm) & Berat nata (g) & Rendemen nata (\%) \\
\hline A1 & $0,46 \pm 0,05$ & 227 & $45 \pm 13^{\mathrm{a}}$ \\
A2 & $0,63 \pm 0,05$ & 248 & $50 \pm 3^{\mathrm{a}}$ \\
A3 & $0,83 \pm 0,11$ & 379 & $76 \pm 13^{\mathrm{b}}$ \\
\hline
\end{tabular}

Keterangan : Angka yang diikuti huruf yang sama pada kolom yang sama berbeda sangat tidak nyata pada uji DMRT $1 \%$

A1 : Nata de coco dengan konsentrasi gula pasir $2 \%$

A2 : Nata de coco dengan konsentrasi gula aren $2 \%$

A3 : Nata de coco dengan konsentrasi gula pasir $1 \%$ : gula aren $1 \%$

Berdasarkan hasil pada Tabel 1, menunjukkan bahwa perlakuan pembuatan nata de coco menggunakan sumber karbon dari gula pasir $2 \%$ (A1) dan gula aren $2 \%$ (A2) menghasilkan rendemen nata masing-masing sebesar $45 \%$ dan 50\%, dimana berdasarkan uji lanjutan menggunakan DMRT $1 \%$ menyatakan berbeda tidak sangat nyata. Sedangkan pada perlakuan penambahan gula pasir dan gula aren dengan perbandingan $1 \%: 1 \%$ (A3), dihasilkan nata dengan tebal sebesar $0,83 \mathrm{~cm}$ dan rendemen diperoleh 76\%. Berdasarkan uji lanjutan menggunakan DMRT 1\% menyatakan perlakuan A3 
berbeda sangat nyata di bandingkan dengan perlakuan A1 dan A2. Ketika gula pasir digantikan seluruhnya dengan gula aren, rendemen yang diperoleh semakin meningkat, tetapi peningkatan yang tidak nyata. Hal ini sesuai dengan penelitian (Suparti, et al., 2007) menunjukkan bahwa ampas sirsak yang hanya ditambahkan dengan gula aren saja memiliki berat nata yang relatif masih rendah atau pembentukan nata belum optimal. Peningkatan yang sangat nyata ketika ada penambahan gula aren dengan komposisi yang sama antara gula pasir dan gula aren. Hasil penelitian (Wijayanti, Hastuti, dan Rohman, 2016) menunjukkan bahwa gula aren dan gula siwalan berpengaruh terhadap tebal dan berat nata dari jeruk pamelo, dimana memberikan hasil lebih baik bila dibandingkan dengan gula pasir. Sedangkan penelitian (Lubis dan Harahap, 2018) menambahkan sari buah merah pada pembuatan nata de coco agar menghasilkan nata yang optimal.

Faktor-faktor yang mempengaruhi keberhasilan dan optimalitas produksi selulosa dari Acetobacter xylinum dan sifat fisiologi dalam pembentukan nata adalah ketersediaan nutrisi dalam medium, sumber karbon, sumber nitrogen, serta derajat keasaman media, temperatur, dan udara (oksigen). Gula pasir maupun gula aren merupakan sumber karbon untuk pertumbuhan bakteri Acetobacter xylinum. Kandungan sumber karbon yang cukup dalam medium mempengaruhi aktivitas metabolisme bakteri Acetobacter xylinum dan berpengaruh terhadap nata yang dihasilkan. Gula aren memiliki keunggulan dan sifat khas yang tidak dimiliki oleh gula pasir antara lain tingginya kandungan sukrosa $84 \%$, gula pereduksi $0,53 \%$, protein $2,28 \%$, kalsium $1,37 \%$ dan posfor $1,37 \%$, sedangkan gula pasir mengandung sukrosa $72 \%$, gula pereduksi $3,7 \%$, protein $0,06 \%$, kalsium $1,64 \%$, dan pospor $0,06 \%$ (Kardiyono, 2010). Keunggulan yang dimiliki oleh gula aren inilah yang menyebabkan dapat meningkatkan rendemen nata de coco. Adanya pencampuran antara gula pasir dan gula aren mempunyai efek yang sinergis dalam pembentukan nata, yaitu dapat meningkatkan rendemen nata yang sangat nyata (Lusi, et al. 2017) melaporkan untuk meningkatkan produksi nata de coco yaitu gula pasir ditambahkan dengan ekstrak teh hitam.

\section{KESIMPULAN}

Kesimpulan yang diperoleh pada penelitian ini adalah bahwa penambahan gula aren dengan perbandingan gula pasir $1 \%$ : gula aren $1 \%$ dalam pembuatan nata de coco dapat mengoptimalkan dalam pembuatan nata de coco dengan rendemen nata yang dihasilkan sebesar 76\%, dimana lebih besar dibandingkan daripada pembuatan nata menggunakan gula pasir dimana rendemen yang didapatkan hanya sebesar $50 \%$. 


\section{UCAPAN TERIMA KASIH}

Ucapan terimakasih disampaikan kepada Politeknik Negeri Tanah Laut yang telah memfasilitasi pelaksanaan kegiatan penelitian.

\section{DAFTAR PUSTAKA}

Asri M.T, Ducha N, Ratnasari E, Bashr A. (2018). Potential of Nata de Legen in Improving Local Wellness of Natural Resources and Human Resources in Dalegan Village, Gresik District. Jurnal Pengabdi Volume 1 No 2.

Hanafiah KA. (2011). Rancangan Percobaan: Teori dan aplikasi. PT. Raja Grafindo Persada. Jakarta.

Hardianti, B. D., Jekti D.S.D dan Lalu Z. (2018) 'Effects of Addition of Soybean sprout cooking water and Acetobacter xylinum to Weight and Thickness of Nata de Pitaya from Dragon Fruit Skin ( Hylocereus polyrhizus )', 12(6), pp. 83-87. doi: 10.9790/2402-1206028387.

Lempang, M (2016). Rendemen dan Kandungan Nutrisi Nata de Pinnata yang diolah dari NIra Aren. Jurnal Penelitian Hasil Hutan. Vol 24 No 2, pp 133-144.

Lubis, A. W. and Harahap, D. N. (2018) 'Pemanfaatan Sari Buah Naga Super Merah (Hylocereus Costaricensis) Pada Pembuatan nata de coco terhadap mutu fisik nata. Journal of Chemistry, 2(2), pp. 1-10.

Lusi, Periadnadi, dan Nurmiati. (2017). Pengaruh Dosis Gula dan Penambahan Ekstrak Teh Hitam terhadap Fermentasi dan Produksi Nata de Coco. Jurnal Metamorfosa IV (1): 126-131.

Rizal, H. M., Pandiangan, D. M. dan Saleh, A. (2013) 'Pengaruh penambahan gula, asam asetat dan waktu fermentasi terhadap kualitas nata de corn', Jurnal Teknik Kimia, 19(1), pp. 34-39.

Suparti, S., Asngad, A. dan Yanti, Y. (2007) 'Pemanfaatan Ampas buah Sirsak (Annona muricata) sebagai Bahan Dasar Pembuatan Nata dengan Penambahan Gula Aren', pp. 1-9. Available at: https://publikasiilmiah.ums.ac.id/handle/11617/1102.

Wardhana, E., Rusmarilin, H. dan Yusraini, E. (2016) 'Pengaruh Konsentrasi Gula dan pH Terhadap Mutu Nata De Yammy Dari Limbah Cair Pati Bengkuang. Jurnal Rekayasa Pangan dan Pertanian, 4(3), pp. 323-331.

Wijayanti E, Hastuti US, dan Rohman F. (2016). Pengaruh Macam Gula terhadap Tebal dan Berat Nata dari Jeruk Pamelo (Citrus maxima (burn. F.) Varietas Nambangan. Prosiding Seminar Nasional II. 